
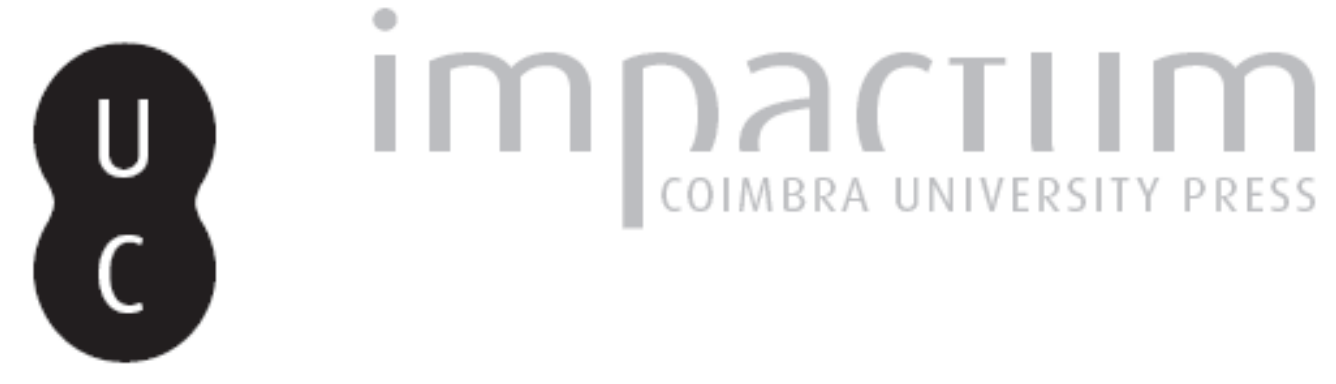

O despotismo fabril: violência e poder numa empresa industrial do calçado

Autor(es): Estanque, Elísio

Publicado por: $\begin{aligned} & \text { Instituto de História Económica e Social; Imprensa da Universidade de } \\ & \text { Coimbra }\end{aligned}$

URL

persistente:

URI:http://hdl.handle.net/10316.2/44498

DOI:

DOI:https://doi.org/10.14195/0870-4147_37_6

Accessed : $\quad$ 26-Apr-2023 04:31:09

A navegação consulta e descarregamento dos títulos inseridos nas Bibliotecas Digitais UC Digitalis, UC Pombalina e UC Impactum, pressupõem a aceitação plena e sem reservas dos Termos e Condições de Uso destas Bibliotecas Digitais, disponíveis em https://digitalis.uc.pt/pt-pt/termos.

Conforme exposto nos referidos Termos e Condições de Uso, o descarregamento de títulos de acesso restrito requer uma licença válida de autorização devendo o utilizador aceder ao(s) documento(s) a partir de um endereço de IP da instituição detentora da supramencionada licença.

Ao utilizador é apenas permitido o descarregamento para uso pessoal, pelo que o emprego do(s) título(s) descarregado(s) para outro fim, designadamente comercial, carece de autorização do respetivo autor ou editor da obra.

Na medida em que todas as obras da UC Digitalis se encontram protegidas pelo Código do Direito de Autor e Direitos Conexos e demais legislação aplicável, toda a cópia, parcial ou total, deste documento, nos casos em que é legalmente admitida, deverá conter ou fazer-se acompanhar por este aviso.

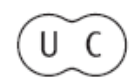




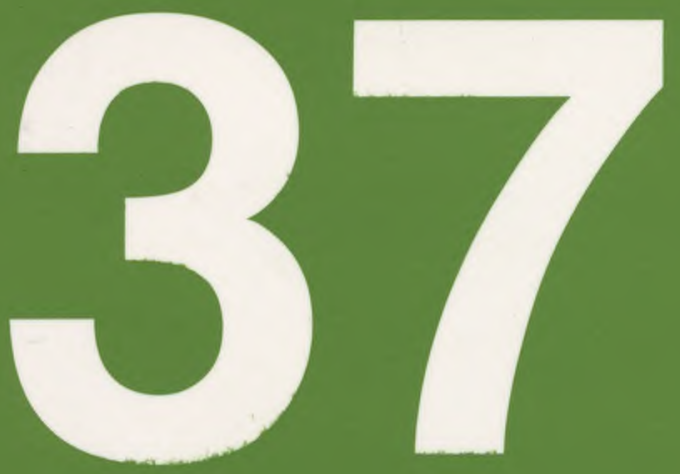

Revista Portuguesa de História

Faculdade de Letras da Universidade de Coimbra Instituto de Historia Econónica e Samial

Coimbra 05 
Revista Portuguesa de Historia

t. XXXVn (2005)

pp. 131-152

\section{O Despotismo Fabril: \\ violência e poder numa empresa industrial do calçado}

ElísIo EstanQue

Centro de Estudos Sociais

Faculdade de Economia da Universidade de Coimbra

Quando me convidaram para escrever um artigo centrado no tema das relações laborais - para um volume temático sobre violência - de imediato me ocorreu a experiência de observação participante que vivi há cerca de dez anos atrás numa empresa industrial do sector do calçado em S. João da Madeira (SJM). É dessa realidade que aqui pretendo dar conta. Optei por um registo que recupera alguns extractos do Diário de Campo que na altura elaborei, e assume uma abordagem auto-reflexiva onde é patente a ambiguidade da posição em que se encontra o investigador. Trata-se, por um lado, de descrever e recriar o ambiente vivido no dia-a-dia da fábrica, mostrando alguns dos contornos e contradições de que se revestem os mecanismos de poder que aí estão em vigor. Por outro lado, dá-se conta do percurso sinuoso do observador, envolvido num mundo social que lhe era estranho, e que se depara com todo um conjunto de desafios, dilemas e opções a que tem de responder nesse quotidiano (onde permaneci durante cerca de três meses).

\section{Enquadramento}

O principal objectivo é partir do registo etnográfico para retratar o ambiente social da empresa, mostrando os principais mecanismos de poder que aí fimcionam. 
Uma das vantagens deste tipo de metodologia reside no facto de ela permitir elaborar uma espécie de arqueologia dos processos de estruturação social, no quadro de um microsistema de características sui generis. Na realidade, a fábrica industrial é um mundo que, para lá da sua aparência rotineira, se vai revelando como repleto de dinamismos - no seio dos próprios operários, com as suas segmentações intemas, entre o colectivo operário e a hierarquia, entre a empresa e a comunidade envolvente, entre homens e mulheres, etc. Além disso, as múltiplas contradições que podem ser detectadas na fábrica evidenciam não apenas fenómenos de âmbito local mas, antes, reflectem os impactos das clivagens estruturais que o capitalismo vem promovendo, no contexto da globalização económica actual. Por outras palavras, trata-se, de pôr em prática o que alguns sociólogos designaram de "método de caso alargado", ou seja, trata-se de procura usar um caso particular para detectar relações causais e linhas explicativas que nos ajudem a compreender as dinâmicas estruturais do mundo social mais vasto onde ele se inscreve (Burawoy, 1979 e 1985; Santos, 1995).

O presente texto insere-se, assim, na mesma linha de estudos anteriores que tenho desenvolvido sobre as relações de trabalho, o sindicalismo e as desigualdades de classe em Portugal (Estanque, 2000, 2003, 2004a, 2004b e 2005). Como é sabido, ao longo dos anos noventa, a temática da articulação entre a indústria e a pequena agricultura tradicional foi apontada como um dos traços específicos das sociedades semiperiféricas, como a portuguesa. Em especial os sectores industriais de mão-de-obra intensiva (como o do calçado) foram assinalados como estando a sofrer processos de implantação difusa, onde se articulam espaços urbanos e rurais, contribuindo para desenvolver culturas e relações laborais particulares, dando lugar a modelos produtivos em que o capitalismo se mistura com modalidades de produção simples, de matriz tradicional ou pré-capitalista (Santos, 1990 e 1993; Reis, 1992).

Os processos mais recentes de fragmentação do trabalho e de precarização das relações laborais têm vindo a tomar ainda mais difícil a capacidade de resistência do movimento operário e sindical contra a hiperexploração de que o trabalhador volta a ser vítima, agora à escala global. Mais de 150 anos decorridos após a publicação do Manifesto - e não obstante a falência histórica da doutrina marxista-leninista - alguns dos postulados teóricos de Marx e Engels continuam a revelar grande actualidade enquanto instrumentos de análise do sistema capitalista. Por outras palavras, a velha clivagem capital-trabalho persiste, já que, considerando essa dicotomia clássica, as grandes transferências de mais-valia continuam a traduzir-se na intensa exploração da classe trabalhadora em favor do capital transnacional.

No entanto, e paradoxalmente, a força crescente do mercado e do capitalismo neoliberal, lado a lado com a sua capacidade de coordenação à escala mundial 
tem decorrido em paralelo com o aumento da debilidade da classe trabalhadora enquanto sujeito colectivo. $\mathrm{O}$ capital une-se e coordena-se enquanto o trabalho se divide e fragmenta cada vez mais. É, pois, neste contexto de profundas mutações sócio-laborais que podemos dizer que - recuperando novamente a referência a Marx - a "luta de classes" deixou de ser o "motor da história" e perdeu significado no terreno político, muito embora se intensifiquem as desigualdades e os mecanismos de exploração ${ }^{1}$.

A força de trabalho é hoje multiétnica, sofre os efeitos da mobilidade e fluidez do capital transnacional, alimenta-se de movimentos migratorios e redes clandestinas de tráfico. Apesar da globalização - e por causa déla -, os sectores mais degradados, pobres e excluidos da classe trabalhadora tendem a "localizar-se" cada vez mais. O velho operariado industrial perde peso demográfico, as leis laborais tomam-se mais flexíveis, os despedimentos mais fáceis (o desemprego aumenta), ao mesmo tempo que emergem e crescem novos sectores proletarizados, sem condições de negociar ou reivindicar de forma organizada. Ou seja, pode dizer-se que "a classe" enquanto actor ou força social perdeu sentido, embora se mantenha - e porventura até se intensifique - o efeito de classe enquanto barreira social, isto é, enquanto factor estruturante do acesso desigual aos recursos (Pakulsky e Waters, 1996; Wright, 1997). São estes processos de profunda recomposição das desigualdades sociais que têm vindo a ser apontados para ilustrar a formação de novas "subclasses locais", a par da emergência de uma nova "sobreclasse" ou também chamada "classe capitalista transnacional" (Estanque, 2005; Sklair, 2001).

Quer isto dizer que com a intensificação destas tendências aperfeiçoou-se a eficácia dos mecanismos de sujeição, e aumentaram extraordinariamente o individualismo, a ideologia consumista, os factores promotores de aceitação, consentimento e alienação dos trabalhadores e dos cidadãos em geral. À luz destes fenómenos e da sua recente expansão no plano global, faz sentido recuperar aqui a expressão "relações na produção", cunhada por Michael Burawoy (1979; 1985), que pode contrapor-se ao velho conceito de "relações de produção". $\mathrm{Na}$ verdade - como a seguir se verá -, quando se observa o fervilhar de uma fábrica industrial no seu quotidiano, mais do que o conflito de classes tradicional, o que salta à vista é todo um conjunto dinâmico de processos de estruturação identitária entre grupos distintos, de diferentes gerações, culturas, categorias 1

\footnotetext{
O processo de segmentação das classes e de fragilização dos movimentos sociais em geral - e do movimento sindical em particular - é de tal maneira poderoso que retirou ao operariado e à classe trabalhadora qualquer capacidade de resposta organizada. Para uma análise aprofundada da temática das desigualdades e do esbatimento da "luta de classes", ver Estanque (2004b e 2005).
} 
profissionais, sexos, etc. O próprio conceito de ideologia é aqui considerado para além do seu velho sentido político-doutrinário, como dirpensão que se enraíza e mistura com outros factores socioculturais. Só com tal procedimento é possível captar a emergência de uma pluralidade de "micro-ideologias" e formas de acção de natureza distinta, umas provenientes do topo da hierarquia, outras da base, umas de sentido "autocrático" e "despótico", outras veiculando formas de rebeldia tácita, outras ainda promotoras de "consentimento" e aceitação (Burawoy, 1985; Therbom, 1980).

\section{2. $O$ sector industrial do calçado}

Estes pressupostos teóricos mais gerais permitem explicitar alguns dos principais traços que tenho utilizado na análise deste sector industrial. Vigora na indústria do calçado um sistema disciplinar que classifiquei de despótico-paternalista (Estanque, 2000 e 2004a), isto é, um sistema de controlo cujos contornos combinam elementos de modernidade técnica com lógicas de gestão pré-modemas derivadas do persistente vínculo entre a indústria e as comunidades tradicionais da região. Sendo Portugal um país semiperiférico da Europa, pode dizer-se que esta é uma região periférica dentro da semiperiferia. Os inúmeros contrastes nos planos cultural e socioeconómico revelam a presença de fenómenos semelhantes aos vividos em países desenvolvidos, como o Reino Unido, há mais de 150 anos. As desigualdades e modelos de controlo em vigor nas empresas recordam-nos os regimes paternalistas do capitalismo inglês à mistura com outros traços mais típicos do despotismo de mercado de certas regiões dos EUA, ambos fenómenos originariamente identificados no século XIX (Burawoy, 1985). Sobretudo nas empresas de pequena e média dimensão, subsiste uma mentalidade empresarial conservadora e orientada para o lucro fácil, que se traduz em modelos de gestão de tipo arbitrário e despótico, em geral misturados com traços de paternalismo. Este tipo de poder autoritário pode, por seu lado, estender-se para fora da fábrica, permitindo ao empresário accionar mecanismos de controlo cujo epicentro se situa na empresa mas que opera simultaneamente na esfera doméstica e da comunidade ${ }^{2}$.

Como sabemos, o grau de violência ou de coerção com que o poder é exercido varia na razão directa do grau de resistência das suas putativas vítimas, seja essa resistência efectiva ou potencial. Autores tão marcantes da sociologia como

2 Por mais que uma vez percebi que quando algum trabalhador dava mostras de maior rebeldia ou que não estava a demonstrar suficiente dedicação ao trabalho, o empregador não tinha dificuldade em estar informado da sua situação familiar, ou, por exemplo, se desempenhava paralelamente outro tipo de trabalhos (para outra empresa ou para si próprio). 
Michel Foucault (1977) e Pierre Bourdieu (1989) há muito teorizaram sobre a ligação indissociável entre as dimensões física e simbólica do poder. Assim, a violência física e simbólica que pauta o ritmo da fábrica dever ser entendida como expressão dos mecanismos de poder e formas de opressão que, em geral, definem as relações sociais na esfera produtiva e em particular no espaço industrial.

No caso da indústria portuguesa de calçado, aqui em análise, e em especial no período nos anos 90 do último século, as modalidades de gestão e os estilos de liderança que prevaleciam neste sector eram facilmente perceptíveis pela própria opinião pública, dada a profusão de notícias relacionadas com conflitos entre os empresários e os seus trabalhadores ou o sindicato. Bastará, por exemplo, atentar em alguns títulos da imprensa escrita para podermos antever a violência que impera nas empresas do sector nesta região: "Sindicalista esfaqueado por empresário do calçado» (Jornal de Notícias, 15/3/88); " 'Seguranças 'agridem sindicalistas em fábrica de S. João da Madeira» (Jornal de Notícias, 20/7/90); «S. João da Madeira - Violência na greve do calçado» (Público, 1/9/93); "Trabalhadores impedem saída de máquinas do interior de fábrica em Arouca - Vigilância no calçado» (Público, 28/10/95); "Patrão e 'seguranças ' condenados por agressão a sindicalistas» (Jornal de Notícias, 15/11/96); "GNR diz que não viu nada - Sindicalistas 'sequestrados'pela entidade patronal» (Jornal da Feira, 8/5/98); "Empresa 'Basilius 'no banco dos réus - 'Haja justiça', pede o sindicato» (O Regional, 22/01/00); "Patrão do calçado condenado por sequestro de sindicalistas» (Jornal de Notícias, 25/3/00).

\section{O empresário e as suas boas intenções}

$\mathrm{O}$ escasso número de empresas que responderam às cerca de três dezenas de faxes que enviei para fábricas de calçado localizadas na zona de SJM contribuiu para aumentar o meu cepticismo acerca deste patronato. O primeiro contacto com o empresário onde acabei por realizar a Observação Participante foi, desde logo, ilustrativa da natureza do poder e da "cultura empresarial" que prevalece neste segmento. É conhecida a fraca sensibilidade da generalidade dos empresários portugueses para com as questões sociais, bem como a sua relativa indiferença para com as condições de trabalho e os direitos dos trabalhadores. Imagine-se a perplexidade de um típico proprietário de uma PME portuguesa quando confrontado perante a situação "bizarra" de um académico se dispor a trabalhar como operário numa linha de montagem. Todavia, este não era, apesar de tudo, um típico empresário do calçado. Não obstante as relações algo ambíguas que com ele mantive ao longo da pesquisa, este proprietário - de uma empresa com perto de 60 trabalhadores, sendo a maioria mulheres - mostrou grande 
entusiasmo no acolhimento que dedicou ao meu trabalho e proporcionou-me todas as condições pretendidas.

Mas, como se deve calcular, o interesse entusiástico do empresário (e Director da empresa) não foi inocente. Fui aos poucos percebendo que a sua estratégia se relacionava com objectivos que ele próprio pretendia alcançar através da minha presença na empresa. O primeiro, refere-se à sua expectativa de que, ao acolher um investigador conotado com a universidade, isso pudesse ajudar a projectar para o exterior a imagem de uma empresa moderna e de espírito aberto, uma empresa que, segundo o próprio dizia, estaria preocupada em se "fixar na linha da frente" em termos de investimento na inovação e na motivação do pessoal. Um empresário dinâmico, orgulhoso de ter conseguido tudo o que tem à sua própria custa. Nas nossas variadas conversas revelou-me que, na juventude, viajou sozinho pelo estrangeiro, onde nos anos sessenta trabalhou em hotéis e restaurantes a lavar pratos, e envolveu-se - tal como o investigador, neste caso - no activismo político do período do pós-25 de Abril (1974-1975). Esta imagem de modernidade com que pretendia conotar a empresa visava atingir a concorrência directa, bem como afirmar o seu protagonismo e eventualmente consolidar a sua posição no mercado. Lado a lado com o repetido discurso da "crise", a ideia de que a empresa se debatia com muitas dificuldades económicas e problemas de escassez de encomendas (um discurso que rapidamente percebi ser mais para consumo intemo, isto é, para trabalhador ouvir), perante a concorrência era necessário, pelo contrario, dissimular os sintomas da crise, além do mais, porque isso teria, ou poderia ter, consequências junto de fornecedores, clientes, banca, etc. As iniciativas inovadoras são ingredientes que podem tomar-se importantes mais-valias e, portanto, é imperioso prestar-lhes atenção. A oportunidade de ter um sociólogo na empresa ajustava-se bem a essa perspectiva, e daí a sua receptividade entusiástica e o grande interesse que manifestou em relação à pesquisa.

A segunda vertente refere-se à tentativa de tirar proveito da minha presença na fábrica para "motivar" os operários, ou seja, da minha colaboração com a direcção poderia resultar algum acréscimo de incentivos à produtividade, sem acréscimo de custos económicos. Assim, a "negociação" tácita entre nós passou pelo meu compromisso em entregar-lhe no final um "diagnóstico" da situação social dos trabalhadores com vista ao desenvolvimento de novas formas de incentivo à produtividade e à motivação do pessoal. Neste campo é possível distinguir duas coisas. Por um lado, a tentativa - supostamente genuína e sem dúvida legítima do seu ponto de vista - de ajudar a criar condições para que os operários se dedicassem mais à vida da empresa, se identificassem mais com ela, procurassem trabalhar melhor, aderissem mais abertamente aos objectivos 
patronais, etc., donde resultariam consequências positivas para ambos os lados. Por outro lado, urna expectativa em relação a possíveis informações que eu poderia veicular-lhe acerca das atitudes dos operários e do seu empenhamento no trabalho ${ }^{3}$.

A conversa informal e o bom relacionamento que prevaleceu entre nós ao longo de todo o período da pesquisa traduziram-se em repetidos convites para passar no seu gabinete ao fim do dia, onde se trocavam impressões, quer sobre o decorrer do meu trabalho quer sobre a situação da empresa e dos trabalhadores. Mantendo sempre a necessária postura conciliadora, porque naquele contexto o seu poder se exercia também sobre mim, não deixei de ter uma crescente sensação de que, à medida que o tempo ia correndo, me encontrava entre uma espécie de fogo cruzado, sofrendo ataques de ambos os lados. Não é difícil imaginar-se as dificuldades que tive em ultrapassar a situação.

Em todo o caso, devo adiantar que, a este respeito, tudo correu conforme o previsto e no final facultei ao proprietário o prometido "diagnóstico", assinalando diversos pontos críticos e apontando um conjunto de sugestões destinadas a flexibilizar a estrutura organizacional e os canais de comunicação da empresa. Não deixa, contudo, de ser significativa a reacção "indignada" do patrão quando soube, semanas depois da conclusão do meu trabalho, que eu tinha participado num debate promovido pelo sindicato onde foram referidos (e depois divulgados na imprensa) alguns dos constrangimentos e práticas autoritárias de que os trabalhadores do calçado são vítimas nas empresas. Apesar de se tratar de uma abordagem genérica sobre o sector e de o nome da empresa nunca ter sido divulgado, isso não me impediu de ser acusado de estar a "fazer o jogo do sindicato", de prejudicar a imagem dos empresários, e até de "traição"...

\section{Entrar no mundo fabril...}

Numa manhã chuvosa de Fevereiro (1996) era ainda noite quando, cerca das 7,40h, me aproximei do polo industrial junto à entrada sul da cidade de SJM. $\mathrm{O}$ intenso movimento de bicicletas, gente a andar a pé no meio da rua, os tendeiros que acabavam de preparar as suas barracas de vendas, o ruído de carros e motocicletas, deram-me a sensação de estar a penetrar num outro mundo. Foi com este sentimento que atravessei o portão da empresa no meu primeiro dia de trabalho.

\footnotetext{
Desde o início que ficou clara a minha posição de neutralidade, assim como a defesa do anonimato em relação a quaisquer situações de trabalho que viesse a detectar no seio do grupo operário. Esta minha posição foi respeitada e compreendida da sua parte. Mas em alguns momentos pareceu-me óbvio o seu desejo de saber mais acerca do que dizem e do que pensam os trabalhadores.
} 
Mal entrei, essa sensação de estranheza agravou-se ainda mais perante a atmosfera densa e agitada da fábrica. Um ambiente escuro, impregnado de odores estranhos de gases, colas e produtos químicos, conjugava-se com os mais variados ruídos do movimento das máquinas, o som das descargas de pressão dos fomos e sistemas de refrigeração, à mistura com os ecos de sons metálicos que ficavam a martelar-me nos ouvidos. A movimentação dos trabalhadores, também ela obedecia a ritmos semi-automáticos. Ao toque da campainha, movem-se os corpos dos operários em gestos rápidos, desdobrando-se em múltiplas tarefas, pegando nas ferramentas e entregando-se ao trabalho sem perda de tempo. Será difícil esquecer os sentimentos contraditórios que me assaltaram nesse momento: ao mesmo tempo uma sensação de angústia e curiosidade, de apreensão e expectativa. "Isto é mesmo a sério", pensei.

Mas a preocupação em começar não me deixou mais tempo para reflexões. Fui de seguida apresentado ao encarregado da linha de montagem (FI), que me conduziu até ao meu posto e me explicou a tarefa que tinha de efectuar, mostrando ele primeiro como se fazia. Após uma rápida explicação e introdução ao meu colega de posto: “... vai ficar aqui ao pé do sr. António a arrancar pregos. Eu vou-lhe explicar como se faz..Foi buscar o arrancador, que é uma espécie de chave de fendas com a ponta em curva e com uma pequena fenda, que tem de se encostar à cabeça do pequeno prego para fazê-lo sair, segurando o sapato (sandália, neste caso) com a mão esquerda e manuseando a ferramenta com a outra. Comecei o meu trabalho.

O calçado surgia do meu lado esquerdo, com os pares enformados e colocados na posição invertida (com as solas para cima), nas aberturas próprias entre os tubos cilíndricos dos carros da linha de montagem. No início vinham dois pares em cada carro, mas por vezes apareciam três. Retirava uma sandália com a mão esquerda e segurando-a contra o peito, procurava os dois pregos e, com algum esforço e as dificuldades iniciais, arrancava-os com a ferramenta da mão direita. Voltava a colocar a sandália no mesmo sítio. Por vezes, era difícil encontrar os pregos, porque eram pequenos e a cor confúndia-se com a da palmilha e, além disso, como esta estava coberta de cola, os pregos não saltavam à primeira tentativa. Tendiam a ficar agarrados à ferramenta ou à sandália. Isto obrigava a mais um movimento com os dedos para os retirar para o chão, sem perda de tempo. A atrapalhação crescia quando, mesmo assim, os pregos teimavam em ficar colados aos próprios dedos. Mas com este modelo de sandália (de Verão), como tinha as palmilhas bastante maleáveis, era fácil arrancá-los, apesar de tudo.

$\mathrm{O}$ pior era a cadência que tinha de ser imprimida. Não paravam de chegar mais carros com os tabuleiros cheios. Logo a seguir ao meu posto, o calçado entrava num forno que se fechava automaticamente e por isso o tempo e o 
espaço de manobra eram muito pequenos. As dificuldades aumentaram ainda mais quando, com o rápido andamento da linha, os do posto anterior (os montadores ou também chamados "pregadores"4) se atrasavam nessa tarefa e vinham depositar os pares nos carros (depois de pregados na palmilha) quando estes já estavam prestes a entrar no fomo. Nesse caso não dava tempo para fazer tudo. Ouvi então os primeiros desabafos de protesto da parte do tio António: "ele não vê que isto está atrasado?"; com ar chateado, nervoso e encolhendo os ombros: "se não vem desligar a máquina e parar isto, deixa-se seguir tudo pr' á frente! !". O meu companheiro de trabalho revelou desde logo ser um incorrigível falador. Perguntou-me se era amigo do FI (o encarregado); eu disse-lhe que não e que estava ali para aprender a fazer sapatos porque me interessava conhecer melhor aquele sector; adiantei que iria ficar apenas por um período curto, de dois ou três meses. Deu-me alguns conselhos, ensinou-me a posição correcta das mãos, para ter cuidado com os dedos e para não me preocupar, que isto "quem não sabe, aprende". Cerca de uma hora depois de iniciado o trabalho, o encarregado geral chamou-me para falar mais um pouco comigo, procurando pôr-me a par dos problemas da produção e querendo saber mais alguma coisa do meu trabalho. Tanto ele como o encarregado da montagem mostraram-se bastante colaborantes para comigo.

\section{Violência psicológica, e física...}

Num dos meus primeiros dias na fábrica assisti logo a uma discussão particularmente violenta entre o encarregado da montagem e o tio António. Como eu estava perto, mas do outro lado da linha, pude observar a cena sem que se apercebessem da minha proximidade, apesar do enorme o ruído não me deixar ouvir todas as palavras. O motivo foi uma sandália mal riscada 5.0 encarregado "berrava" que "só o trabalho bem feito é que se quer, mal feito não vale a pena!". A cara vermelha e nervosa do meu companheiro a gritar igualmente para o seu chefe e virando-lhe as costas, com o outro a gritar que olhasse para ele, enquanto o tio António continuava a falar e a esbracejar numa expressão de rebeldia ostensiva e descontrolada. Fiquei a meditar naquela cena passada a

4 Trata-se da função propriamente de montagem do sapato, isto é, corresponde ao trabalho de pregar, com o auxílio de uma máquina, as biqueiras e calcanheiras (também os chamados "bicos" e "tacões") na sola/palmilha do calçado, ainda enformado.

5 Riscar consistia em fazer um risco em redor da palmilha, colocada no exterior, na parte de baixo do sapato (ainda enformado), de modo a saber-se quais os limites até onde se devia colocar a cola para mais tarde fixar a respectiva sola. 
cerca de um metro de distância. Um adulto com 62 anos e perto de trinta de experiência operária a reagir irritado mas com os olhos no chão, como uma criança intimidada. O mesmo homem que dias antes tinha oferecido ao outro, que agora o humilhava, uma garrafa do seu vinho caseiro. Pedira-me a mim para lha entregar, certamente porque temia que os colegas dessem conta desse gesto e o vissem como um acto de "graxice". Agora, ali estava ele, irado mas numa postura submissa a responder quase contorcido, tentando defender a sua dignidade. Segundo mais tarde me revelou, respondeu que "não é só aqui que se ganha dinheiro! Na baixa também se ganha dinheiro! !’. E com isto invocava a sua debilidade física e denunciava a falta de reconhecimento pela sua dedicação ao trabalho e à empresa. Como quem diz, "se a firma não me quer cá, se já não presto, posso meter baixa em vez de estar aqui a aturar-vos".

Este caso ilustra bem a dimensão simbólica que o trabalho pode representar na vida de uma pessoa. Não é apenas uma necessidade de subsistência, uma vez que, como era o caso, com a exploração agrícola do pequeno terreno, somado ao trabalho da mulher (trabalhava de tarde a fazer limpezas numa quinta), permitia-lhe amealhar algum dinheiro e justificar uma eventual reforma antecipada antes do limite de idade (dada a sua saúde precária), que seria suficiente para o casal sobreviver sem grandes aflições. Mas, a ligação à actividade fabril era já muito longa e profunda. Precisava de estar ali para se sentir útil e activo. A partilha, o convívio diário e o respeito e amizade dos colegas compensavam o esforço físico que tinha de despender. Por outro lado, foi interessante verificar que se invocava a situação de "baixa" como se ela representasse algum privilégio, ideia que, aliás, parecia estar presente em alguns sectores da força de trabalho, nomeadamente quando se ouviam comentários contra os "abusos" de quem "metia baixa” muitas vezes (porventura sem justificação).

O mesmo responsável da secção de montagem relatou-me aspectos bem ilustrativos dos cuidados que presidem à relação de poder que mantinha com os operários. Sublinhava a sua preocupação em que tudo saísse bem feito, mas também as dificuldades em levar os trabalhadores a fazer as coisas segundo "o método correcto". Reconhecia que o operário que já está no seu posto há vários anos tem geralmente uma experiência muito grande, mas referiu também as dificuldades com que se deparou para combater os "vícios". Sublinhou, com ênfase, que os operários tentavam sempre fazer as coisas à maneira deles: "por vezes da maneira mais difícil, até para eles". E isto porque, acrescentou, "além de se cansarem mais, rendem menos".

Falou dos primeiros tempos como encarregado em que, afirmou, alguns lhe tentaram "fazer a vida negra (...). Estavam sempre a apalpar o pulso. Se sentiam que era mole abusavam logo (...) Havia coisas em que ainda tinha pouca prática, 
mas sempre fui procurando melhorar até saber fazer bem, como hoje, qualquer operação na linha de montagem. Quando é preciso mostrar, sento-me ao lado do operador e mostro-lho como se deve fazer (..Reconheceu que, por vezes, embora as coisas não saíssem exactamente como ele queria, deixava passar. E, para concluir, afirmou: "Ainda hoje isso acontece, mas eu apercebo-me!, (...). Eles pensam que não, mas eu se fecho os olhos é porque quero (...)".

A propósito dos gritos que por vezes dirigia a esta ou àquela operária, avançou a seguinte explicação: "dantes eu costumava chegar ao pé delas e chamar a atenção. Dava a volta pelos diferentes postos e controlava as coisas. Mas comecei a perceber que elas me queriam trocar as voltas. Quando eu me ia dirigir a alguma que estava a conversar ou a fazer asneira, elas percebiam e nessa altura mudavam de lugar. Outras vezes eram as outras que ficavam atrás de mim que me chamavam quando eu me encaminhava para um certo posto (...)". Esta acção de resistência ou, nas suas palavras, de "boicote" ao papel do "responsável", levou-o nessa altura a fazer uma reunião com todos os trabalhadores (dos acabamentos e montagem) em que anunciou as novas regras: "A partir de agora ninguém sai do seu posto de trabalho sem minha autorização. Se vejo alguém fora do posto sem motivo, vai imediatamente lá para fora". Outras afirmações suas - que me foram mais tarde transmitidas, durante uma reunião com todos os encarregados - são bem reveladoras da visão que tinha do seu próprio papel e dos operários que chefiava. Usando sempre um tom irrefutável e paternalista explicou: "É preciso ter uma linguagem técnica para toda a gente dizer da mesma maneira (...). Não se pode dar a entender ao subordinado que ele tem razão, porque se ele pensa que sabe mais, perde o respeito (...). Se ele é incorrecto, é preciso ser firme e não dar parte de fraco (...). Eu sou um encarregado! E como encarregado [ênfase], como profissional que sou, ensino como se faz! Não se pode mostrar fraqueza, se apalpam e sentem que é mole (...)!"

\section{Os jogos de poder do colectivo operário}

Situar a forma como se configuram as relações de poder entre os operários e os encarregados é reconhecer que os operários têm poder. Ou seja, é reconhecer que eles estão longe de ser meras peças da máquina produtiva ou meros repositórios de um poder unidireccional que sobre eles é exercido. Na linha de Michael Burawoy (1979, 1985 e 2001), podemos assumir a ideia de que o taylorismo nunca conseguiu, na prática, consumar por completo a separação entre concepção e execução. Os responsáveis da gestão, embora tenham chamado a si o controle do conhecimento técnico, não conseguiram nunca monopolizá-lo. Trata-se assim de reconhecer uma nova oposição entre o conhecimento apropriado 
pela Direcção e o conhecimento dos trabalhadores. É a parte que lhes cabe do seu saber-fazer que lhes permite pôr em prática processos mais ou menos subtis que tendem a contrariar as regras da hierarquia e, de certo modo, recriar "a unidade entre concepção e execução". O processo de produção capitalista não se limita, portanto, a estruturar objectivamente uma classe. Do mesmo passo, modela subjectivamente as identidades colectivas e individuais através da experiência vivida pelos trabalhadores no processo de produção. As relações na produção, além de não serem uniformemente determinadas pelo modo de produção capitalista, traduzem-se em experiências específicas, em jogos informais que podem assumir-se como formas ideológicas ou, digamos, "micropolíticas", cujo efeito pode ser o de conciliar as relações de produção, dando lugar ao que Burawoy designou de "fabricação do consentimento".

Porém, neste caso, tal consentimento não é totalmente conseguido. Autores como Michel de Certeau (1984), Mikhail Bakhtin (1984) ou John Fiske (1993) há muito chamaram a atenção para a importância das "tácticas" de resistência, das acções de perversão "carnavalesca" e das técnicas de "farsa" a que se dedicam os indivíduos, sobretudo quando sujeitos a formas de opressão e exclusão social. O espaço produtivo deve olhar-se como não circunscrito ao seu conteúdo meramente económico. Mesmo num contexto fabril de tipo despótico conseguem-se esculpir alguns espaços de liberdade (Crozier e Friedberg, 1977) com base no saber técnico, nas regras do jogo que se aprendem a dominar, na subtileza da pequena sabotagem, etc., ou seja, os trabalhadores recusam a ser tratados como máquinas, procurando por diversos meios estender as chamadas zonas de incerteza (Bemoux, 1985), em que a relação de poder se inverte pontualmente. De algum modo, pode dizer-se que a prática repetida do "jogo" informal se transmuta na necessidade dos subordinados aceder a uma certa forma de liberdade (Burawoy, 1985). Podemos, assim, reconhecer que na fábrica, como noutros contextos, os actores em posições de subordinação nunca são totalmente dependentes. Como assinalou há uns anos um outro conhecido sociólogo, há uma dialéctica de controle que dá lugar a constantes desequilíbrios, viragens e cedências que alteram continuamente a distribuição do poder (Giddens, 1982: 32).

Estes são contornos e dimensões de que se revestem as relações sociais em contextos particulares muito diversos, mas que, como pretendo a mostrar neste texto, proliferam no espaço fabril. Na empresa onde trabalhei, estas diferentes formas de acção pareciam operar numa espécie de zona de penumbra, em que só procurando os gestos mais subtis e a sua repetição ao longo do tempo se pode detectar neles algum conteúdo subversivo. As formas de "jogo" que a interacção adquire na empresa são visíveis sobretudo na relação entre o grupo operário e as chefias directas. Mas, a estrutura de poder insere-se, naturalmente, 
num quadro mais abrangente. Remete sobretudo para o vértice da pirâmide social da empresa.

O patrão parecia observar e registar atentamente qualquer gesto que the parecesse sinal de facilitismo na linha de montagem. Se notava que em algum posto havia "tempos mortos", não se esquecia mais tarde de atirar ao chefe do respectivo sector que havia pessoal "a arranjar as unhas...", forma curiosa de denunciar o trabalhador que aproveitou algum subterfúgio momentâneo para abrandar o ritmo. Esta dependência dá algum crédito aos que afirmam que os "berros" do encarregado se fazem sentir em especial quando o patrão está por perto. Isto permite-nos ainda reforçar a ideia de que não se trata tanto de um poder arbitrário pessoal, mas de toda uma lógica disciplinar fundada num regime de tipo autocrático, onde o ritmo produtivo tem de se traduzir na constante "transpiração" do operário. Na verdade, as chamadas sweat shops e os Mc Jobs associados à globalização económica expandiram-se bastante desde os anos 80 do século passado. Mas, aqui ao nosso lado, em SJM, o cansaço, o suor e a violência quotidiana na linha de montagem são uma constante desde há várias décadas, com a agravante de que, ao contrário de outros sectores da nossa indústria, nas PMEs do calçado nunca existiu um regime fordista de produção. Ou seja, trata-se de um tecido empresarial onde a legislação e os direitos laborais raramente ou nunca foram realmente levados a sério pelos empresários ${ }^{6}$.

Os métodos autoritários em vigor na linha de montagem foram repetidamente por mim presenciados. As raparigas mais jovens eram as vítimas preferenciais. Embora fosse, até certo ponto, compreensível que por serem mais inexperientes pudessem errar mais, pareceu-me claro que havia aí uma selectividade calculada. É também notório neste sector - continua a sê-lo - que o poder masculino se sobrepõe ou se articula com a dominação de classe, mantendo a mão-de-obra feminina como a parte mais precarizada da força de trabalho. É por esse motivo

6 Importa aqui recordar que grande parte das unidades produtivas do calçado eram nesta altura, e continuam a ser, predominantemente microempresas, a maioria delas sem estatuto formal/ /legal (aquilo que na gíria se designa por "empresas vão-de-escada"). Acresce que as características de "economia subterrânea" e a estreita articulação entre as unidades industriais e a produção doméstica (muitas vezes alimentada por trabalho infantil, bastante denunciado nos 1990 em Portugal), funcionando em regime de subcontratação, com encomendas de tarefas específicas do calçado, em geral pagas à peça, são factores que têm nas últimas décadas favorecido o crescimento de múltiplas situações de precariedade, em particular porque se trata de um sector de trabalho intensivo, vivendo de mão-de-obra barata e sem qualificação. Daí que, como tenho referido noutros artigos, o sector do calçado possa ser referido como um exemplo onde vigora o modelo pós-fordista, mas que, no entanto, nunca passou pelo fordismo (Estanque, 2004a e 2005). 
que, conforme pude testemunhar durante a minha observação, o autoritarismo dos encarregados assumia sempre formas mais arrogantes quando era dirigido às mulheres. $\mathrm{O}$ grito de longe era o método mais frequente: "vem cá contar-me essa que eu também queria ouvir!"; "então o que é que eu sou aqui afinal?... Aquilo que eu digo é para se fazer ou quê?!". Tal como com estas raparigas jovens - conhecidas na fábrica pelo "pessoal de Alvito" - assisti a outras situações de grande violência, sempre dirigidas a trabalhadores de menores recursos. Um dia, o chefe da montagem chamou uma das operárias e pediu-lhe para desenformar umas botas (das chamadas "amostras"7) quando ela se encontrava junto das embalagens. Como naquele momento estava a acabar outra tarefa, respondeu: “já vou”. Pouco depois, e como não visse a sua ordem seguida de imediato, o encarregado foi junto dela e gritou-lhe: "mas o que é que eu estou aqui a fazer?!". Numa furia crescente, que para mim era até então fora do comum, gritava: “queres ir lá para fora? Queres?!”. "Ir lá para fora” era uma forma de punição que vigorava na empresa. Uma trabalhadora podia ser mandada para a rua durante um período de tempo variável, sendo-lhe depois descontado esse tempo no ordenado.

O tio António (o meu companheiro de posto de trabalho) e a Rosa são exemplo disso. Em ambos os casos, o encarregado mostrava-se particularmente irritado com o facto de olharem para o chão quando lhes dirigia alguma reprimenda. Vi-o a gritar para o meu colega de posto: "Olhe para mim! Olhe para mim carago! Porque é que não olha para mim?”. O caso da Rosa é semelhante. São ambos trabalhadores sem qualquer instrução escolar e cujas marcas de ruralidade saltavam à vista. A sua postura corporal perante a posição de poder com que eram confrontados imprimia-lhes no rosto uma expressão semelhante à de crianças desprotegidas e envergonhadas quando repreendidas em público.

Estes casos eram o oposto da atitude dos jovens mais qualificados e instruídos que trabalhavam na linha de montagem. Enquanto estes evidenciavam sinais de segurança, indiferença e até de autoridade - inerentes ao capital educacional e às qualificações técnicas que possuíam -, os primeiros demonstravam embaraço, retraimento e medo. Mas, apesar disso, por vezes também o tio António se mostra revoltado com o chefe. Quando o andamento da linha era demasiado violento, explodia: “ele não vê que isto está atrasado?!". Chateava-se, ficava vermelho de irritação e protestava: "se não vem desligar a máquina e parar isto, deixa-se seguir tudo pr'á frente e pronto! (...)”. Noutras ocasiões, tanto o

\footnotetext{
Pares de calçado que eram produzidos em número limitado - e em geral com um design mais arrojado -, destinados a ser exibidos nas feiras internacionais desta indústria.
} 
tío Antonio como os outros, adoptavam uma atitude deliberada de "deixa andar". Se viam que o encarregado não tomava atenção à excessiva velocidade da linha, como sabiam que não ganhavam nada em protestar abertamente e também não queriam ser cooperantes em excesso, abrandavam o ritmo de propósito e ficavam "nas calmas", como que a assobiar para o ar, fingindo que não percebiam o que se estava a passar. Notava-se o prazer que sentiam quando viam o encarregado em apuros. Esta constitui, evidentemente, uma forma de resistência comum à generalidade do trabalho operário. Mas aqui assume traços muito próprios.

"Ele sabe a quem as faz!", comentava o Paulo a propósito da lógica selectiva que preside aos comportamentos despóticos do seu chefe. Para com os homens, de um modo geral, não existiam atitudes ostensivamente arrogantes. As excepções que pude constatar foram o tio António e o Pedro, sendo este acusado pelos seus colegas de "dar confiança demais" ao encarregado. Os pequenos desentendimentos e situações de tensão com os meus ex-colegas "pregadores" assumiam em geral contornos bastante mais subtis. Essas situações quase sempre se deviam a problemas técnicos do processo de fabrico. Como já disse, o facto de os pregadores ocuparem um posto decisivo, o facto de serem homens, ainda jovens, com alguma qualificação, e sem dúvida também por não mostrarem medo na relação com o chefe (usando a sua linguagem, "não lhe dar confiança"), são aspectos que contribuem decisivamente para que a relação com o encarregado assumisse de facto uma forma diferente. ${ }^{7}$

\section{Uma irreverência surda e corrosiva...}

A dada altura detectou-se que as sandálias estavam a sair com as gáspeas assimétricas e o FI mandou desmontar algumas delas, instruindo os operários para manterem os "ponteados" da parte direita e esquerda do extremo das tiras da frente à mesma distância da palmilha. Como era costume, ficaram a olhar para a "obra" que tinham nas mãos, aceitando a solução proposta, mas pareciam desconfiados acerca da sua eficácia. A aura de certeza que o chefe colocava quando dava a sua opinião contrastava claramente com a falta de confiança que os outros apontavam nas suas competências. No caso dos homens da montagem (os "pregadores" atrás referidos) era opinião unânime que ele entendia pouco de cada operação em particular. Com isso pretendiam, evidentemente, afirmar a sua própria competência técnica, ou seja, o domínio em relação a um posto que era "o seu", aquele onde trabalhavam todos os dias.

Eis uma situação ilustrativa: Um dos pregadores tentava executar as instruções recebidas. Mais um pequeno retoque, com o encarregado ao lado, este disse: "está bom"; enquanto o primeiro acenava com a cabeça num gesto concordante 
balbuciando, pouco convicto: "está bom". Após o outro virar costas, ao passar ao meu lado com a sandália na mão para a colocar no carrinho, acrescentou: "está uma merda, mas enfim..Minutos depois, os três operários comentavam entre si que aquilo assim estava ainda pior, dizendo que o problema era do molde que estava mal feito, pois, pregando as extremidades das tiras horizontais à mesma distância ficava a tira vertical (do meio da gáspea) descentrada. O Pedro era o que falava mais alto com desabafos de contrariedade e protesto, e isso acabou por chamar novamente a atenção do encarregado, desencadeando assim mais uma reprimenda: “quando se dá uma ordem é para se cumprir! Não é para se ficar a discutir!”. Quando o FI se aproximou já os outros dois pregadores (João e Paulo) estavam ao largo, sentados nos seus postos. Apercebi-me que enquanto o chefe ralhava com o Pedro, estes dois trocavam sorrisos e olhares cúmplices entre si. Explicou-me um deles mais tarde que quando querem "criar confusão" arranjam uma forma de "atiçar" aquele colega contra o encarregado. "Nós começamos a picá-lo, fazemos soltar as cachorras ${ }^{8}$ e pronto... quando as cachorras começam a rosnar está a confusão armada!"

As cachorras rosnaram, o "domador" apareceu, deu dois berros e, pouco depois, já se podia ver o Pedro a trabalhar sossegado. Minutos depois olhou para mim de longe e esboçou um sorriso como que a dizer: "não há nada a fazer. Se ele diz que é assim, assim se fará". Mas não ficam convencidos. Mais tarde ainda voltaram a especular se "amanhã ou depois" não os mandariam desfazer a "obra" e fazer tudo de novo. Muitos detectavam erros, mas não chamavam a atenção porque achavam que "não ganham para isso". Os desabafos repetiam-se: "ele não liga nada"; "ele agora quer duma maneira, mas daqui a bocado se lhe der na cabeça já quer outra coisa (...). Às vezes por causa duma cagadela de mosca faz para aí um barulho do carago! Agora aparecem as palmilhas neste estado, com uma bela merda de trabalho e não dizem nada!!!...". Esta revolta surda, bem como as atitudes de boicote e de chacota, eram expressão da convicção dos operários de que o encarregado, apesar dos seus "ares de conhecedor" era de competência duvidosa. Sintoma disso era o prazer que sentiam ao relatar episódios como este: um sapato não estava bem acabado, o chefe pediu a um dos operários para dar um jeito e este disse: "está bem, deixe ficar". Passado algum tempo, mostrou-lhe novamente o mesmo sapato que supostamente estaria arranjado mas que, em rigor, não alterou absolutamente nada, ao que o encarregado respondeu: “está bem assim, mete na linha, manda p'rá frente!”. E divertiam-se imenso com isso.

Significa isto, levá-lo a protestar e a irritar-se contra o encarregado. 
Estes casos revelam bem o significado simbólico das cumplicidades e da rebeldia tácita dos trabalhadores face à lógica da empresa. $\mathrm{O}$ papel do trabalho na construção das identidades de grupo passa muito por situações deste tipo. Os momentos de tensão, de resistência e de transgressão exprimem o carácter dinámico das relações de poder e mostram que não estamos perante uma atmosfera de total passividade ou de mera aceitação por parte do trabalhador. Trata-se, antes, de um jogo em que cada um dos actores se faz valer dos mais diversos meios para marcar pontos face ao adversário. Nomeadamente, no caso dos operários, é visível uma atitude aparentemente passiva, mas que é na verdade uma estratégia que passa por dissimular a aceitação. Pode, no fundo, considerar-se isso como urna forma de defesa face a possíveis represálias e ao mesmo tempo uma forma de "disfarce" tendente a enganar o adversário. Assim se procura resguardar para os próprios uma certa margem de manobra, dando ao mesmo tempo sequência a um processo em que - objectivamente - se define e redefine tanto a identidade do grupo como o próprio sentido de dignidade individual do operário. Paralelamente, surgem situações e momentos em que a relação de poder parece inverter-se, em que a posição dominante pode pontualmente comutar com a posição subordinada.

Já se sabe que os trabalhadores detêm um certo poder, na medida em que a empresa e as chefias precisam deles, não apenas para estarem presentes no posto de trabalho mas para que, em maior ou menor grau, se dediquem efectivamente e apliquem as suas capacidades e talentos no processo produtivo. Tratando-se de uma empresa onde não existem instrumentos formais de negociação, isto é, onde o trabalhador não possui nenhum meio de afirmar abertamente os seus interesses, as suas respostas podem surgir como uma docilidade resignada ou assumir uma forma de "rebelião contida". No contexto aqui abordado, as duas situações parecem misturar-se e altemar-se. O retraimento controlado ao longo do tempo pode conduzir a situações "explosivas" ou de descontrolo, como se viu, enquanto que noutras ocasiões assume contornos mais corrosivos onde a transgressão é, como disse, marcada pela subtileza.

Como atrás já referi, embora de passagem, a desigualdade sexual ocupa também um lugar central na dinâmica da empresa. Convém, pois, assinalar esta questão. A força física, a coragem, a capacidade de enfrentar a dureza da vida, constituem ingredientes que fazem parte do discurso e do imaginário masculinos, na base de uma lógica que simboliza a posição dominante do homem, tanto perante o trabalho como perante a mulher. Apesar da presença maioritária de mulheres na indústria do calçado, as relações na produção são manifestamente caracterizadas pela masculinidade. Por outro lado, as desigualdades de género, quer no que respeita ao acesso a posições qualificadas quer mesmo no caso dos 
níveis salariais, são particularmente evidentes, e até chocantes, neste sector específico da indústria portuguesa. De facto, vigoram aí duas tabelas salariais, em que na prática uma se destina aos homens e outra às mulheres, não obstante essa discriminação objectiva ser objecto de algum disfarce formal (Estanque, 2000) ${ }^{9}$. A hegemonia do discurso masculino, a rudeza das relações entre os trabalhadores, o jogo sexual e a linguagem de índole machista constituíam características bem presentes nesta empresa. Além disso, existia uma demarcação de espaços entre ambos os sexos - dentro e fora da produção, diga-se - e, em certa medida, as próprias mulheres entravam nesse mesmo jogo sem o alterarem substancialmente ${ }^{10}$. Em todo o caso, estas reacções de aparente "desrespeito" podiam ser toleradas não só por serem excepções, mas porque o esforço produtivo e a capacidade dos seus diferentes intervenientes tendiam a sobrepor-se à disciplina formal, em particular porque situações como aquela anunciam a importância das relações informais e a sua inevitável interferência na cadeia hierárquica.

A observação desta empresa comprova bem a relativa fluidez do sistema e mostra que os trabalhadores não são nem meros suportes do modo de produção nem simplesmente lubrificantes de uma estrutura imutável. Os elementos de rigidez e de maleabilidade do sistema de controle são duas faces da mesma moeda. Todas as partes participam activamente no jogo de poderes interno. Assim, se um primeiro olhar, mais superficial, poderia dar-nos a ilusão de uma absoluta estagnação, uma observação mais atenta não deixou de revelar como os diferentes intervenientes participavam activamente na estruturação das relações de trabalho num processo vivo e dinâmico, composto de múltiplas rupturas e continuidades. Essa dinâmica ficou bem visível na análise das relações de poder entre as chefias intermédias e os trabalhadores desta fábrica.

Os encarregados pareciam evidenciar o desconforto de quem caminha na fronteira. A clivagem incontomável entre quem pertencia ao grupo operário, ou com ele era identificado, e quem estava "do outro lado", obrigou a opções claras. E se alguém, por força das coisas, tinha de manter-se na ambiguidade, via-se na necessidade de fazer uso de uma ginástica constante. O responsável da secção de costura (AB) disse-me um dia que um chefe é sempre visto como

9 Veja-se em especial os Anexos do meu livro Entre a Fábrica e a Comunidade (Estanque, 2000), onde se apresentam essas duas tabelas salariais (A e B) e também a estrutura das categorias profissionais do sector distribuídas segundo o sexo.

10 É exemplo disso o relato do "romance na fábrica", na obra citada. Vale a pena ainda referir a observação das diversas brincadeiras entre rapazes e raparigas, bem como a demarcação de espaços, também evidentes durante os intervalos. Veja-se Estanque (2000:309-315, páginas impares). 
"lacaio do patrão", revelando perceber bem a lógica dominante, mostrou até o seu sentido crítico face aos mecanismos de exploração em que está inserido. AB mantinha relações de alguma proximidade com os operários, muito embora tal não acontecesse com os seus subordinados directos. Um dos trabalhadores que lhe era mais próximo confidenciou-me que, quando estava junto do seu sector a sua postura se altera totalmente, procurando salvaguardar as distâncias perante os seus subordinados (que eram sobretudo mulheres). Outro aspecto curioso e sintomático é o facto de $\mathrm{AB}$ não almoçar no próprio balneário junto dos outros operários, mas num espaço lateral e algo escondido. Segundo me explicou, não se sentia bem a comer no refeitório em frente às operárias. $\mathrm{Na}$ sua opinião, elas reparavam em tudo e comentavam tudo: "se um tipo come com o garfo ou com a colher, se come sandes ou comida quente, etc. (...). Não se pode dar muita confiança". Preferia suportar o isolamento e o mau cheiro - pois o balneário ficava na mesma divisão dos WCs - a ter de enfrentar os olhares, ou seja, a partilha do espaço de informalidade e de descompressão que era o refeitório na hora de almoço.

\section{Conclusão}

A partir da observação directa no contexto específico de uma empresa de calçado foi possível verificar como a esfera laborai é de facto um mundo cheio de contradições. É conhecida e identificada como característica da sociedade portuguesa a elevada margem de tolerância que os subordinados admitem relativamente ao exercício da autoridade por parte dos seus superiores hierárquicos. Quem ocupa posições de destaque e lugares de chefia exige uma dedicação sem limites por parte dos subordinados, enquanto os próprios subordinados, ou por falta de alternativas ou porque esperam daí retirar algum retomo, não raro, deixam-se enredar numa lógica de resignação, alimentada por sentimentos de lealdade incondicionais, amplificando assim os recursos de autoridade dos seus superiores. Daí que, quando esses laços de afinidade e dependência se quebram e a parte mais fraca começa a invocar direitos, se assista muitas vezes a reacções violentas, mais abertas ou mais subtis, dando lugar a fenómenos de violência psicológica e de assédio moral no trabalho, quando não de violência física, como mostrei neste texto (Estanque, 2003 e 2004b).

As divisões existentes na sociedade portuguesa são expressão das barreiras sociais instaladas e do défice de participação democrática quer na esfera pública em geral que no campo laborai em particular. Persistem na nossa sociedade fortes contradições de classe, mas a importância crescente da precariedade, ao lado de todo um conjunto de fenómenos - associados ao consumismo, 
à liberalização da economia e à força do mercado - tendem a minar as capacidades de resistência organizada da força de trabalho. Isto impede que tais contradições estruturais assumam hoje um significado político relevante, seja enquanto estímulo para a acção colectiva e reivindicativa, seja enquanto capacidade negocial ao nível da empresa. No actual panorama, quando a relação salarial é cada vez mais precária, o trabalhador sabe que pode a qualquer momento ser descartado. O conhecido "exército de reserva" continua a ser uma enorme força dissuasora. E perante isso o sindicalismo português tem-se revelado totalmente impotente. Daí, o retraimento, os mecanismos subjectivos de fuga, de evasão mental, o medo de retaliações, etc., que, apesar de alimentarem em geral um forte sentimento de contrariedade no trabalho, se traduzem na recusa em participar no activismo sindical ou noutras formas de intervenção associativa.

Em suma, a observação apresentada, retratando o contexto de um operariado precário e ainda semi-rural (sobretudo em meados dos anos 1990, altura em que decorreu a observação), permitiu visualizar uma multiplicidade de formas, jogos, tensões e processos sociais que têm lugar no quotidiano da empresa. A complexidade que caracteriza uma pequena unidade industrial como a que aqui foi analisada permitiu identificar e revelar alguns dos impactos locais das estruturas socioeconómicas da sociedade portuguesa e do próprio capitalismo global. Com o operariado a precarizar-se cada vez mais e a implodir enquanto classe capaz de se organizar colectivamente, ao mesmo tempo que o sindicalismo se fixa nos (poucos) sectores com emprego relativamente estável e seguro, poderemos estar à beira de um cenário que a prazo corre o risco de tomar-se desastroso em termos de conflitualidade social. Espera-se, portanto, que quer o panorama económico de crise internacional, quer a eficácia das políticas govemativas, quer ainda a capacidade de acção dos parceiros e actores sociais no seu conjunto, possam conjugar-se favoravelmente para que o trabalho, a coesão social e a justiça social recuperem dignidade, importância e viabilidade no horizonte de uma sociedade mais democrática, mais justa e mais desenvolvida.

\section{Referências Bibliográficas}

BAKHTIN, Mikhail (1984) - Rabelais and his World. Bloomington: Indiana University Press.

BERNOUX, Philipe (1985) - La Sociologie des Organisations. Paris: Seuil.

BOURDIEU, Pierre (1989) - O Poder Simbólico. Lisboa: Difel.

BURAWOY, Michael (1979) - Manufacturing Consent. Chicago: The University of Chicago Press.

BURAWOY, Michael (1985) - The Politics of Production. Londres: Verso. 
BURAWOY, Michael, et al., (2001) - Global Ethnography: forces, connections, and imaginations in a postmodem world. Berkeley/LA: University of California Press.

CROZIER, Michel e Erhard Friedberg (1977) - L 'Acteur et le Système. Paris: Seuil. de CERTEAU, Michel (1984) - The Practice o/Everyday Life. Berkeley: University of California Press.

ESTANQUE, Elisio (2000) - Entre a Fábrica e a Comunidade: subjectividades e práticas de classe no operariado do calçado. Porto: Afrontamento.

ESTANQUE, Elisio (2003) - “O efeito classe média: desigualdades e oportunidades no limiar do século XXI", in Cabral, M. Villaverde, J. Vala e A. Freire (orgs.) - Desigualdades Sociais e Percepções de Justiça. Lisboa: Imprensa de Ciências Sociais (ICS), pp. 69-105.

ESTANQUE, Elisio (2004a) - "A reinvenção do sindicalismo e os novos desafios emancipatórios: do despotismo local à mobilização global", in Santos, Boaventura de Sousa (org.) - Trabalhar o Mundo: os caminhos do novo internacionalismo operário. Colecção «Reinventar a Emancipação Social: Para Novos Manifestos», Vol. 5. Porto: Afrontamento, 297-334.

ESTANQUE, Elisio (2004b) - "Mudanças e clivagens no mundo do trabalho: novas tecnologias ou novas desigualdades?", in Estanque, et al. (Orgs.), Relações Laborais e Sindicalismo em Mudança: Portugal, Brasil e o contexto transnacional. Coimbra: Quarteto, pp. 107-132.

ESTANQUE, Elisio (2005) - "Trabalho, Desigualdades Sociais e Sindicalismo", Revista Crítica de Ciências Sociais, 71.

FISKE, John (1993) - Power Plays, Power Works. Londres: Verso.

FOUCAULT, Michel (1977) - Vigiar e Punir. Petrópolis: Editorial Vozes.

GIDDENS, Anthony (1982) - "Power, the dialetic of control and class structuration", in Giddens e Mackenzie (eds.), Social Class and the Division of Labour. Cambridge: Cambridge University Press.

PAKULSKY, Jan e Malcolm Waters ( 1996) - The Death of Class. Londres: Sage. REIS, José (1992), Os Espaços da Indústria. Porto: Afrontamento.

SANTOS, Boaventura de Sousa (1990) - O Estado e a Sociedade em Portugal (1974-1988). Porto: Edições Afrontamento.

SANTOS, Boaventura de Sousa (1993) - "O Estado, as relações salariais e o bem-estar na semiperiferia: o caso português" in Boaventura de Sousa Santos (org.), Portugal - Um Retrato Singular. Porto: Afrontamento.

SANTOS, Boaventura de Sousa ( 1995) - Toward a New Common Sense. Londres/ /Nova Iorque: Routledge.

SKLAIR, Leslie (2001) - The Transnational Capitalist Class. Oxford/ Malden, MA: Blackwell. 
THERBORN, Gõran (1980) - The Ideology ofPower and the Power of Ideology.

Londres: Verso.

WRIGHT, Erik Olin (1997) - Class Counts. Cambridge: Cambridge University Press. 